Review of Amerika to Chügoku (America and China) by MATSUO

Fumio. Tokyo: Iwanami Shoten, January 2017

\title{
TAO De-min*
}

This is a remarkable book that attempts to remind the Japanese people of the underlying history of the formidable symbiotic relationship between the two great continental countries on both sides of the Pacific that is much longer and deeper than the US-Japan relations that began formally with Perry's visits to Japan during the early 1850s.

Born in1933 in Tokyo, Matsuo Fumio（松尾文夫） is known as one of the foremost experts in Japan on American political affairs. As a correspondent for Kyodo News to New York and Washington, D.C. during the Cold War years, he wrote in 1971 the famous article, "Nixon's America: Its

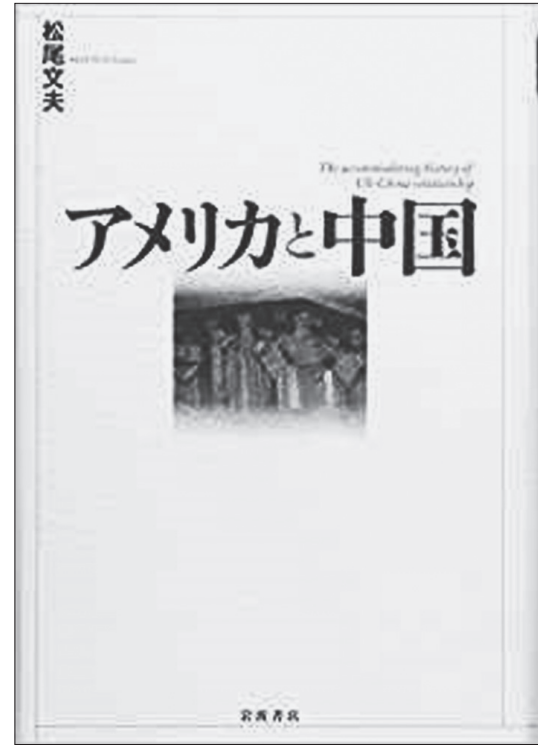

Statue of Confucius (Center), Supreme Court, Washington, D.C. (1937) Formidable Approach to China," shortly before Henry Kissinger's secret visit to China, predicting correctly the historic reconciliation of the two countries. In recent years, he has published Democracy with a Gun: The Making of America (2004), and The Day When President Obama Pays a Floral Tribute to Hiroshima (2009). Obama's May 2016 visit to Hiroshima is more evidence of his insightful predictions.

Matsuo started this book-length research from 2004 when he was shocked by the long list of 637 missionaries sent by the American Board to China, which he obtained from Harvard's Houghton Library. He had hoped to find a reasonable explanation for why the Japanese failed to understand the subtle relations between the U.S. and China and launched reckless aggressive wars against both countries in the 1930s and 1940s. The search for an answer took him almost 14 years of frequent travels to the two continents and countless

* TAO De-min is the founding President of the Society. 
interviews with scholars abroad as well as here in Japan, including myself when I was visiting Tokyo and doing sabbatical research at Beijing University in the summer of 2012. As he stated in the Afterword, because he did not know the Chinese language well and lacked experience as a foreign correspondent in China, he had to rely upon the help of many experts. Thus, the book contains much of the latest research by Chinese, American, and Japanese scholars, which is very informative and impressive, and helps readers to easily obtain an overview of the field.

The ten chapters of the book are as follows:

1 Robert Morris (1734-1806) as a Founding Father of America: To Find a Means of Survival in Trade with China

2 Confucian Thought that Impacted Early Modern Europe

3 The Relationship Began with Utilitarian Business

4 The Separation of Principle and Practice Started with the Opium War

5 Becoming a Great Power with a Pro-Chinese Image

6 The Age of a "Special Relationship" and Discrimination

7 The "Red Tie" between Mao Tse-tung (Mao Zedong) and America: From Baoding to Changsha

8 The "Red Tie" between Mao Tse-tung (Mao Zedong) and America: The Deep Influence Left by John Dewey (1859-1952)

9 The Distance between Chiang Kai-shek (Jiang Jieshi) and America

10 The Betrayal of the "Open Door" Policy: The Fall of Chiang Kai-shek

The book has a stimulating prologue entitled "Beginning with Nationbuilding Energy from Philadelphia" and includes a 27-page-long Chronology of US-China Relations, starting with the founding of the Shang (Yin) Dynasty ca. 1600 BC, and ending with Obama's floral tribute to Hiroshima in 2016. Some readers may wonder why Matsuo traced the chronology to China's golden age in the Shang, the second of the so-called Three Dynasties, some thirty-seven centuries ago, when the history of US-China relations is at most 230 years long if counted from the visit of the first merchant ship Empress of China to China in 1784-1785, which was financed by Robert Morris. Taking a look at the Chronology and Chapter 2, "Confucian Thought that Impacted Early Modern Europe," one may find that Matsuo sees the formation of the United States as an extension of the European civilizations that had intensive cultural contacts with China and were profoundly influenced by Confucian thought in the early modern age. For example, Benjamin Franklin published articles on Confucian morals in the Pennsylvania Gazette in 1737, and the renowned Chinese play, Sacrifice (Zhaoshi guer in Chinese, 
and Shina no koji in Japanese), was performed in Philadelphia in 1757, which were four and two decades earlier, respectively, than the 1776 War of Independence that led to the founding of the United States.

It seems to me that Matsuo is a bit too critical of American attitudes toward China. Although he mentions many good things the Americans did for China, such as restrictions on the opium trade, the Burlingame Treaty of 1868, the "Open Door" policy proposed by John Hay, the educational and medical undertakings by missionaries as represented by the Yale-in-China association's involvement in Changsha, Hunan Province, and so forth, he emphasizes that there were a series of "serious" betrayals. He states that these started with the confidential Taft-Katsura Agreement of 1905 that gave mutual assurances on the status quo in the Philippines and Japan's suzerainty of Korea, and the desirability of Japan, the U.S., and Britain of cooperating to achieve peace in the Far East. He argues that the consolidation of Japan's position in Korea gave Japan better and more opportunities to invade the mainland from the peninsula. In other words, although American imperialism had a pro-Chinese image, on critical issues related to their national interests, the Americans would never compromise.

My viewpoint is, however, is that there have always been different groups and opposite opinions at any given time, just as the present-day U.S. is called the "divided states" because of the conflicts between pro-Trump and antiTrump groups concerning policies on immigration, Obamacare, and global warming countermeasures. It is also difficult to define the real national interests of a nation at any particular moment. But we do see some differences between nations. For example, my own research on Samuel Wells Williams, a close colleague and friend of Anson Burlingame during the latter's tenure as the American Minister in Beijing in the 1860s, shows his concern and efforts for promoting an amicable working relationship with China. This included a proposal for establishing a Sino-American college using the surplus of the reparation money obtained from the Qing government to train diplomats, traders, and interpreters, which was approved by President Lincoln, though Williams was also known for the successful insertion of the tolerance clause in the Tianjin Treaty of 1858 to allow Protestants to preach in China.

With the help of such scholars as Tang Zhouyan 唐洲雁, author of Mao Tse-tung's Views of America (Mao Zedong de Meiguo guan), Matsuo realized there was a "red tie" between Mao and the U.S., as symbolized by John Dewey's influence on Mao during Dewey's lecture tour in China in 1919 in terms of taking a realistic view of and pragmatic attitude toward the world. Matsuo believes this may well explain why Mao was able to respond so sensitively some fifty years later to President Nixon's formidable approach to China that was based on the latter's five-power centers thesis presented in his 
Kansas City speech in 1971.

In the meantime, however, we should not forget that Mao, during his lifetime, had absorbed much wisdom from Chinese history and statecraft, such as the diplomatic tactics displayed in the Romance of the Three Kingdoms (三国演義). At the end of the 1960s, both the U.S. and China needed to overcome a dilemma: the U.S. was eager to escape from the bog of the Vietnam War, and China wanted to avoid a potential atomic attack by the Soviet Union. Thus, they approached each other to find a way out, and acted as formidable players in the multipolar world newly defined by Nixon.

In the epilogue entitled "The Symbiotic Relationship of Two Competitors," Matsuo again uses his preferred Japanese expression of shitatakasa to describe a perfect combination of idealism and pragmatism in Chinese and American attitudes toward each other. I like this wording, too, because I believe it reveals the truth of US-China relations. Like any bilateral relations, the US-China relationship also has the nature of promoting and checking each other at the same time (相生相克). I think that just as the purpose of Ezra Vogel in writing Japan as Number One was to warn the American people that they would fall behind the rising Japanese industrial power if they continued the status quo without making further effort, the motivation of Matsuo to publish this study was to try to reconsruct a better US-Japan relationship by warning the Japanese people that they have to better understand what is going on in current US-China relations, the relations between the two biggest and interdependent economies. These relations have deep roots, as symbolized by the Empress of China's visit to China in the early modern era, a visit that occurred seventy years earlier than that of Commodore Perry to Japan. As Matsuo's mentor, Matsumoto Shigeharu (松本重治, the founder of I-House in Roppongi, Tokyo), has frankly pointed out, Japan-US relations are nothing more than Japan-China relations, and Japan-China relations are nothing more than Japan-US relations（日米関係は日中関係である。日中関係は日米関係であ る). 